\title{
EFFECT OF CHOLINE AND LECITHIN ON GROWTH AND FEED EFFICIENCY OF JUVENILE HUMPBACK GROUPER, Cromileptes altivelis
}

\author{
Ketut Suwirya and Nyoman Adiasmara Giri
}

\begin{abstract}
This experiment was conducted to determine the effect of supplemental choline and lecithin in the diet of juvenile humpback grouper. Four treatments were designed in a $2 \times 2$ factorial design and diets containing $0 \%$ or $8 \%$ lecithin and $0 \%$ or $0.9 \%$ choline chloride were fed to hatchery produced juvenile of $3.9 \pm 0.2$ gram body weight. They were reared in 30 liter polycarbonate tank and stocked 15 fish in each tank. All tanks were equipped with flow through system. Fish were fed with experimental diet three times a day for 7 weeks. The results of the experiment showed that the growth and feed efficiency of humpback grouper were affected by supplemental choline and lecithin. An interaction effect was observed between supplemental dietary choline and lecithin on fish weight gain $(192.5 \%$ to $240.5 \%)$ and feed efficiency $(46.9 \%$ to $73.29 \%)$.
\end{abstract}

KEYWORDS: choline, lecithin, humpback grouper, Cromileptes altivelis

\section{INTRODUCTION}

Choline is generally classified as an essential vitamin by most comparative nutritionists. This substance is an important component of phospholipid lecithin and certain other complex lipids. It serves as a source of labile methyl groups for synthesis of various ethylated metabolites and as precursor of acetylcholine. Most animals can synthesize choline if adequate methyl donors such as methionine are present in the diet. The rate of choline synthesis has been shown to be insufficient to meet the metabolic and physiologic needs in some young animals (Wilson and Poe 1988). Therefore, choline should be presented in the diet for normal growth.

Dietary essentiality and deficiency signs of choline have been reported on common carp (Ogeno et al. 1970), red sea bream (Yano, 1975), Japanese eel (Arai et al., 1972) and red drum (Craig and Galtin, 1997). Deficiency signs have been reported to include poor growth and feed efficiency, anorexia and fatty liver.

Some information is available on the requirement of choline for fish. The choline requirement of common carp appears to be not more than $1,500 \mathrm{mg} / \mathrm{kg}$ of diet (Ogeno et al., 1970). Halver (1972) reported that Chinook and Coho salmon require $600-800 \mathrm{mg}$ choline $/ \mathrm{kg}$ of diet based on maximum liver storage data. Hung et al. (1987) showed that juvenile white sturgeon fed purified diet containing $8 \%$ refined soybean lecithin had better growth when compared to those fed diet without lecithin. Dietary sources of phospholipid such as soybean lecithin were essential for growth and survival of red sea bream and flatfish
(Kanazawa et al., 1985 and Kanazawa, 1993; 1997). These studies also suggested that soybean lecithin may be required by hatchery produced juvenile humpback grouper. The present research was conducted to determine the effect of supplemental choline and lecithin in the diet of juvenile humpback grouper.

\section{MATERIALS AND METHODS}

Formulation and proximate compositions of the four experiment diets are shown in Table 1 . The four treatments were designed in a $2 \times 2$ factorial design, and the diets contained $0 \%$ or $8 \%$ soy lecithin (LOC) and $0 \%$ or $0.9 \%$ choline chloride $(\mathrm{Ch})$.

Hatchery produced juveniles of humpback grouper, $3.9 \pm 0.2 \mathrm{~g}$ in average body weight and $4.1 \mathrm{~cm}$ in total length, were stocked in $30 \mathrm{~L}$ polycarbonate tanks with density of 15 fish per tank. Each tank was equipped with flow through water system and aeration to maintain water quality in the rearing tank. The fish were fed with experimental diet three times every day at satiation level.

Data of body weight, total length, and survival rate were recorded every week. At the end of experiment, the livers were quickly dissected from two randomly selected fish from each tank, weighed, freeze dried, and kept at $-20^{\circ} \mathrm{C}$ until analyzed for lipid content. Lipid content of livers (pooled samples) was analyzed using chloroform-methanol (Blight and Dyer, 1957). Crude protein, lipid, and ash of diets were analyzed following the standard methods (AOAC, 1985). All data were analyzed by two-way ANOVA. If there was interaction, means were compared using one-way ANOVA and differences between treatment means were considered significant at $p<0.05$. 
Table 1. Composition of the four experiment diets

\begin{tabular}{|c|c|c|c|c|c|}
\hline \multirow{2}{*}{\multicolumn{2}{|c|}{ Ingredient }} & \multicolumn{4}{|c|}{ Type of diet } \\
\hline & & 1 & II & III & IV \\
\hline \multicolumn{2}{|c|}{ Casein } & 38.00 & 38.00 & 38.00 & 38.00 \\
\hline \multicolumn{2}{|c|}{ Shrimp meal } & 29.80 & 29.80 & 29.80 & 29.80 \\
\hline \multicolumn{2}{|c|}{ Asthaxanthin } & 0.19 & 0.19 & 0.19 & 0.19 \\
\hline \multicolumn{2}{|c|}{ Dextrin } & 14.21 & 14.21 & 14.21 & 14.21 \\
\hline \multicolumn{2}{|c|}{ Mineral mix ${ }^{1}$} & 2.50 & 2.50 & 2.50 & 2.50 \\
\hline \multicolumn{2}{|c|}{ Vitamin mix $^{2}$} & 1.10 & 1.10 & 1.10 & 1.10 \\
\hline \multicolumn{2}{|c|}{ Squid oil } & 10.00 & 2.00 & 10.00 & 2.00 \\
\hline \multicolumn{2}{|c|}{ Lecithin $^{3}$} & 0.00 & 8.00 & 0.00 & 8.00 \\
\hline \multicolumn{2}{|c|}{ Choline chloride } & 0.00 & 0.00 & 0.90 & 0.90 \\
\hline \multicolumn{2}{|c|}{ Cellulose } & 1.20 & 1.20 & 0.30 & 0.30 \\
\hline \multicolumn{2}{|c|}{ CMC } & 3.00 & 3.00 & 3.00 & 3.00 \\
\hline \multicolumn{6}{|c|}{ Proximate composition } \\
\hline \multicolumn{2}{|c|}{ Moisture } & 5.21 & 4.72 & 4.85 & 5.21 \\
\hline \multicolumn{2}{|c|}{ Crude protein } & 55.68 & 55.55 & 55.78 & 54.64 \\
\hline \multicolumn{2}{|c|}{ Lipid } & 10.16 & 11.10 & 10.16 & 10.95 \\
\hline \multicolumn{2}{|c|}{$\mathrm{N}$-free extract ${ }^{4}$} & 18.58 & 17.79 & 19.25 & 19.28 \\
\hline \multicolumn{2}{|c|}{ Fiber } & 4.07 & 4.26 & 3.57 & 3.16 \\
\hline \multicolumn{2}{|c|}{ Ash } & 6.30 & 6.58 & 6.39 & 6.80 \\
\hline \multicolumn{6}{|c|}{$\begin{array}{l}\text { Mineral mix. (mg/100 g diet): } \mathrm{KH}_{2} \mathrm{PO}_{4} 412 ; \mathrm{CaCO}_{4} 282 ; \mathrm{Ca}\left(\mathrm{H}_{2} \mathrm{PO}_{4}\right) 618 ; \\
\mathrm{FeCl}_{2} 4 \mathrm{H}_{2} \mathrm{O} 166 ; \mathrm{ZnSO}_{4} 9.99 ; \mathrm{Mn} \mathrm{SO}_{4} 6.3 ; \mathrm{CuSO}_{4} 2 ; \mathrm{CoSO}_{4} 0.05 ; \mathrm{KJ} 0.15 ; \text { dextrin } \\
\text { 450; cellulose } 553.51\end{array}$} \\
\hline \multicolumn{6}{|c|}{ 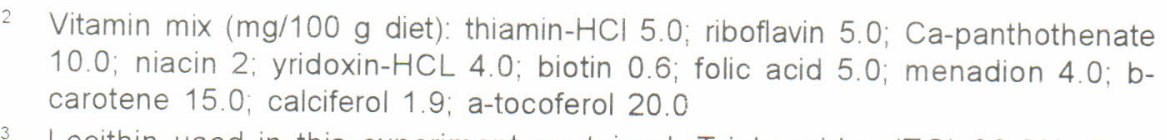 } \\
\hline \multicolumn{6}{|c|}{$\begin{array}{l}3 \text { Lecithin used in this experiment contained: Triglycerides (TG) } 39.8 \% \text {; Free } \\
\text { fatty acid (FFA) } 1.7 \% \text {; Monoglycerides (MG) } 2.4 \% \text {; Phosphatidylethanolamine } \\
\text { (PE) } 24.8 \% \text {; Phosphatidylcholine (PC) } 28.2 \% \text {; other } 3.2 \%\end{array}$} \\
\hline \multicolumn{6}{|c|}{$4 \quad \mathrm{~N}$-free extract $=100-($ moisture + crude protein + lipid + fibre + ash $)$} \\
\hline
\end{tabular}

\section{RESULTS AND DISCUSSION}

Initial average body weight of humpback grouper, Cromileptes altivelis was $3.9 \mathrm{~g}$ and increased from $192.5 \%$ to $240.4 \%$ after 7 weeks. An interaction effect was observed between different dietary choline and lecithin treatments on fish weight gain $(192.5 \%$ to $240.5 \%$ ) and feed efficiency (46.9\% to $73.29 \%$ ), but not on feed intake (13.1g to $16.1 \mathrm{~g}$ ) (Table 2).

Analysis of variance showed that weight gain, feed intake, feed efficiency, and hepatosomatic index ( $\mathrm{HSI}=$ liver weight/body weight $\times 100 \%$ ) were significantly affected by both supplements $(p<0.05)$. Humpback grouper fed with the control diet (diet I) had significantly lower percentage weight gain and feed efficiency and higher feed intake than those fed with diets either one or both supplements (diets II, III, or IV). The weight gain of humpback grouper fed with the diet supplemented with lecithin (diet II) was significantly lower than those fed diet with diets III and IV. The feed efficiency of humpback grouper fed with diets II and III was not significantly different, but fish fed with diet II was significantly lower than those fed diet with both supplements (diet IV). The HSI of humpback grouper fed with diets containing supplemental choline or lecithin or lecithin and choline (diet II, III, and IV) was not significant $(P<0.05)$ but significantly higher than that fed with diet control (diet I). The results of this experiment showed that to attain good growth humpback grouper may require choline and lecithin. The same result was found on juvenile white sturgeon, Accidence transmontanus (Hung and Lutes, 1988).

Table 3 shows that the dry matter of liver was not affected by dietary choline or lecithin, but on the contrary, dietary choline and lecithin affected lipid content of the liver. Wilson and Poe (1988) showed that liver lipid content of channel catfish was affected by dietary choline. This observation is also consistent 
$D$ which can release choline from the phosphatidylcholine (Table 1, footnote 3). Further studies are needed to isolate and to determine the activity of phospholipase-D to confirm the ability of humpback grouper to use dietary lecithin. These results suggest that choline is superior to lecithin for humpback grouper in the present study. Other studies are needed to determine the real choline requirement of humpback grouper.

Recently, various experimental results have shown the beneficial effects of dietary phospholipid supplementation in larval and juvenile stages of several species of fish such as European sea bass and carp (Guerdon et al. . 1995 a, b), Japanese flounder (Tago et al., 1999) and red sea bream (Kanazawa, 1997). The essentiality of phospholipid for aquatic animals is assumed to be due not only to limited ability for phospholipid biosynthesis from diglyceride, but also to its function as an emulsifier of triglycerides and cholesterol, and as a constituent of lipoproteins essential for the transport of lipid.

\section{CONCLUSION}

Juvenile humpback grouper (Cromileptes altivelis) requires dietary choline and lecithin for good growth. Dietary choline is superior to dietary lecithin for their growth.

\section{ACKNOWLEDGEMENTS}

Financial assistance was provided through Improved Hatchery and Grow-Out Technology for Grouper Culture in the Asia-Pacific Region (Project No. FIS/97/73) of ACIAR for which we are most greatfull.

\section{REFERENCES}

Arai, S., T. Nose, and Y. Hashimoto. 1972. Qualitative requirements of young eels, Anguilla japonica for water-soluble vitamins and their deficiency symptoms. Bull Freshwater Fish. Res. Lab. Tokyo, 22: $69-83$

AOAC 1985. Official Methods of Analysis, $14^{\text {th }}$ end, WashIngton, p. 1018

Blight, E.G. and W.J. Dyer. 1957. A rapid method of total lipid extraction and purification. Canadian. J. Brioche. Physiology, 37: 911--917

Craig, S.R. and D.M. Galtin. 1997. Growth and body composition of juvenile red drum (Sciaenops ocelatus) fed diets containing lecithin and supplemental choline. Aquaculture, 151: 259--267.
Guerdon, I., N. Charlton, D. Marion, and P. Begot. 1995a. Dietary phospholipid and body deformities in carp, Cyprinids cardio larvae. In: P. Lavins, E. Jaspers, and I. Roelant (Eds.). Lavi 95. Fish and shellfish symposium, Gent. Belgium. Euro. Aqua Cult. Soc. Spec. Pub. 24: 162--165

Guerdon, I, P. Courtesan, and P. Surgeons. 1995b. Dietary phospholipid for European sea bass (Dicentrachus labrax) during first on growing. In: P. Lavins, E. Jaspers, and I. Roelant (Eds.). Lavi 95. Fish and shellfish symposium, Gent. Belgium. Eur. Aquacult. Soc. Spec. Pub., 24: 175--178

Halver, J.E. 1972. The vitamins. In: J.E. Halver (Ed). Fish Nutrition. Academic Press, New york. p 29--103

Hung, S.S.O., B.J. Moore, C.E. Bordner, and F.S. Conte. 1987. Growth of juvenile white sturgeon (Acipenser transmontanus) fed different purified diets. J. Nut. 117 328--334

Hung, S.S.O. and P.B. Lutes. 1988. A preliminary study on the no-essentiality of lecithin for hatchery-produced juvenile white sturgeon (Acipencer transmontanus). Aquaculture, 68: 353--360.

Kanazawa, A., S. Teshima, S. Imamura, and $H$ Matamoras. 1985. Effect of dietary phospholipids on growth of the red sea bream and knife jaw. Men. Fact. Fish. Kagoshima University. 32: 109--114

Kanazawa, A. 1993. Essential phospholipid of fish and crustaceans. In. S.J. Kinship and P. Loquat (Eds.) Fish nutrition in practice IV. International Symp. On Fish Nutrition and Feeding. INRA, France, p: 519-530

1997. Effect of docosahexaenoic acid and phospholipids on stress tolerance of fish. Aquaculture, 155: 129--134

Lee, D.J. and R.O. Sinnhuber. 1972. Lipid requirement. In: J.E. Halver (Ed.) Fish Nutrition. Academic Press Inc., New York, p. 145--180.

Ogeno, C., N. Uki, T. Watanabe, Z. Aida, K. Ando. 1970. B vitamin requirement of carp IV Requirement for choline. Bull. Jpn. Soc. Sci. Fish., 36: 1140--1146.

Tago, A., Y. Yamamoto, S. Teshima, and A. Kanazawa. 1999. Effects of 1,2-di 20:5-Phosphatidycholine (PC) and 1,2-di-22: 6-PC on growth and stress tolerance of japanese flounder (Paralichtys olivaceus) larvae. Aquaculture, 179: 131--239.

Wison, R.P. and W.E. Poe. 1988. Choline nutrition of fingerling chanel catfish. Aquaculture, 68: 65--71.

Yano, Y. 1975. Nutritional studies of red sea bream. In: K.S. Prince W.N. Shaw and K.S. Denbert (Eds). Proceeding of the First International Conference on Aquacultute Nutrition. Lewes/Rehobot, University of Delaware, p 34--39. 